Department of Theriogenology,

Faculty of Veterinary Medicine,

Assiut University.

\title{
POSTPARTUM UTERINE INVOLUTION AND LUTEAL ACTIVITY IN FARAFRA EWES LAMBING IN AUTUMN
}

(With 3 Figures)

\author{
By \\ D.R. DERAR; M. HAYDER*; A. ALI and H. HAMDOUN** \\ * Animal Production Research Institute, Dokki, Egypt. \\ ** Dept. of Animal Production, Faculty of Agriculture, Sohag Univ., Egypt.
}

(Received at 17/10/2011)

\section{أوب الرحم ونشاط النسيج الأصفر في نعاج الفرافرة بعد الولادة في الخريف \\ ضرار رفعت ابراهيم ، محد حبير ، أحد مصطفي حسين ، حاتم حدون}

صممت هذه الدراسـة لتقدير الوقت الـلازم لاستكمال أوب الرحم بعد الو لادة ونشـاط النسيج

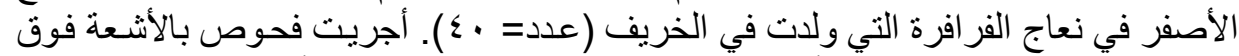

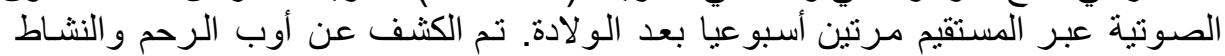

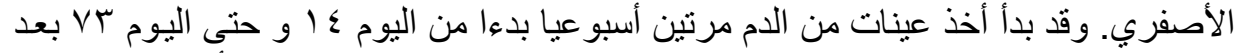

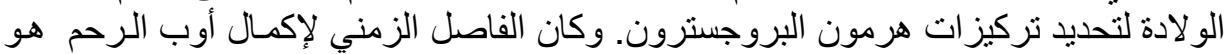

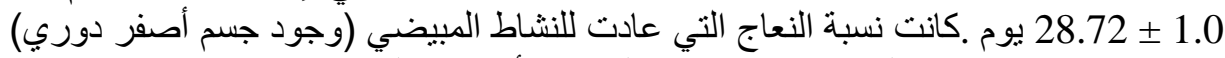

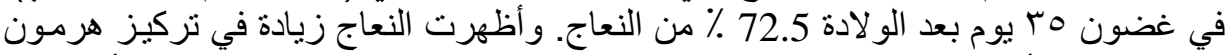

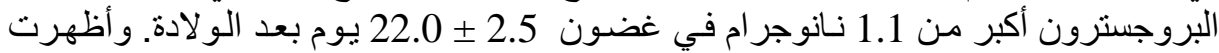

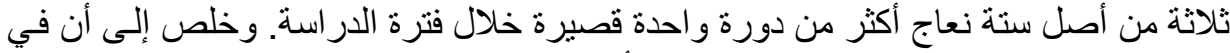

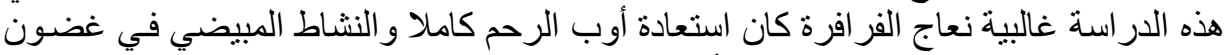
هب يوما بعد الو لادة خلال موسم ولادة الكتوبر في المان المناطق شبه الاستو ائية.

\section{SUMMARY}

The study was designed to estimate the time needed for complete uterine involution and postpartum luteal activity in Farafra ewes lambing during autumn $(\mathrm{n}=40)$. Transrectal ultrasonographic examinations were performed twice weekly after parturition. Uterine involution and luteal activity were detected ultrasonographically. Blood sampling (twice 
weekly) was started on d 14 until d 73 postpartum to determine progesterone concentrations. The mean interval for complete uterine involution was $28.72 \pm 1.0 \mathrm{~d}$. The proportion of ewes that showed the presence of a cyclic CL within $35 \mathrm{~d}$ of lambing was $72.5 \%$. Farafra ewes showed a progesterone concentration greater than $1 \mathrm{ng} / \mathrm{ml}$ at $22.0 \pm 2.5 \mathrm{~d}$ postpartum. Three out of six ewes showed more than one short cycle during the observation period. In this study, it is concluded that the majority of farafra ewes had a complete uterine involution and luteal activity within 35 days post partum during October (lambing season) in the subtropics.

Key words: Ewes, uterine involution, luteal function, postpartum, progesterone.

\section{INTRODUCTION}

The postpartum period is ultimately important for the reproductive efficiency of sheep, especially for those managed under accelerated lambing system with 3 breeding seasons per year (February, June, and October) as the case for farafra ewes. Effects of lambing seasons (February vs. June), parity, number of lambs, dam's body weight, and total milk production on uterine involution and luteal function of Farafra sheep have been evaluated (Hayder and Ali, 2008). February lambing season was more favorable for uterine involution; while the other estimated factors and their interactions had no effect.

Blood concentrations of progesterone are good indicators of luteal function during the postpartum period since progesterone is the major steroid synthesized by the corpus luteum (Stabenfeldt et al., 1969; Swanson et al., 1972). Season affected the onset of the luteal function with the majority of June lambing ewes which showed the first corpus luteum within $42 \mathrm{~d}$ of parturition. In one study (Kotwica et al., 1990), Luteal phases of first oestrous cycles were short and lasted approximately 6 days, whereas normal length of oestrous cycles and progesterone concentration illustrating the presence of cyclic corpus luteum were observed on the $25^{\text {th }}$ day after postpartum. Frequently, the re-establishment of ovarian cyclicity, post partum, is associated with inadequate or subnormal luteal phases, due to the development of CL of short lifespan or CL of normal lifespan but decreased progesterone secretion (Wright et al., 1983; Goodman, 1994). A delayed resumption 
of postpartum ovarian function was observed in highly lactating ewes. Time to complete uterine involution and the onset of postpartum luteal function has not been investigated in Farfara ewes lambing in autumn.

The aim of this study was therefore to use ultrasound examinations and progesterone analysis to estimate the time needed for completion of uterine involution and the onset of luteal function, as well as the postpartum progesterone profiles in Farafra ewes lambing in autumn.

\section{MATERIALS and METHODS}

\section{Animals and Management}

A total of 40 fat-tailed Farafra ewes (primipara, $n=5$ and multipara, $n=35$ ) that lambed in autumn (from October, 14 to October, 24) were used in this study. The average age and body weight at lambing were $52 \pm 22.3$ months and $39.5 \pm 2.1 \mathrm{~kg}$, respectively. All studied ewes were clinically healthy and had no history of difficult parturition or postpartum complications. The lambs were kept with their mothers until weaning at 8 weeks after birth. Ewes were not exposed for rams during the experimental period. The experiment was carried out at Mallawi Animal Production Research Station of the Animal Production Research Institute ( $22^{\circ} 42$ latitude and $30^{\circ} 45 \mathrm{E}$ longitude). The sheep flock was managed under an accelerated lambing system with 3 breeding seasons / year (February, June, and October) where ewes have the chance to get in lamb twice per year. The current study was conducted following October lambing season $\left(23.3 \pm 0.5{ }^{\circ} \mathrm{C}\right.$ average atmospheric temperature and 53.0 $\pm 1.2 \%$ average relative humidity). The ewes were housed in semi-open pens, water was available twice daily, and mineral blocks were available all the time. The animals were fed on a concentrate mixture with wheat straw, providing $14 \%$ crude protein $(\mathrm{CP})$ and $70 \%$ total digestible nutrients (TDN).

\section{Ultrasonic examinations for the postpartum uterus and ovaries}

Transrectal ultrasonographic examinations were performed for all ewes twice weekly, starting $3 \mathrm{~d}$ after parturition. A B-mode scanner (Hitachi, EUB-405B, Tokyo, Japan) attached with a $5 / 7.5 \mathrm{MHz}$ transrectal linear array transducer was used for the examinations. The ewes were restrained in a standing position. The transducer with some ultrasonic jell was introduced into the rectum, and moved a little bit medially and laterally to get the best view of the examined uterus. The 
maximum diameter of the previous gravid horn was taken on nearly the same point on the base of the horn at each examination for each ewe on fixed screen of the ultrasound.

Uterine involution was considered to be completed when there was no further reduction in the uterine diameter for three successive examinations. According to Ali et al. (2006). The postpartum luteal activity was considered to be started by detecting a corpus luteum larger than $9 \mathrm{~mm}$ in diameter for three successive examinations.

\section{Blood sampling and progesterone determination}

Jugular blood samples were collected twice weekly from 6 ewes. Sampling was started on d 14 and extended until d 73 postpartum. Serum was harvested and kept at $-20{ }^{\circ} \mathrm{C}$ until analyzed for progesterone. Serum concentrations of progesterone were determined by RIA utilizing kits provided by Diagnostic System Laboratories, Inc. (USA, Cat. 3900). The sensitivity of the assays was $0.12 \mathrm{ng} \mathrm{mL}^{-1}$, and the intra- and interassay precision had a coefficient of variance of 4.6 and $9.7 \%$, respectively.

\section{Statistical analysis}

The data were analyzed using the General Linear Models procedures of the SPSS-program version 11.0 (2001).

\section{RESULTS}

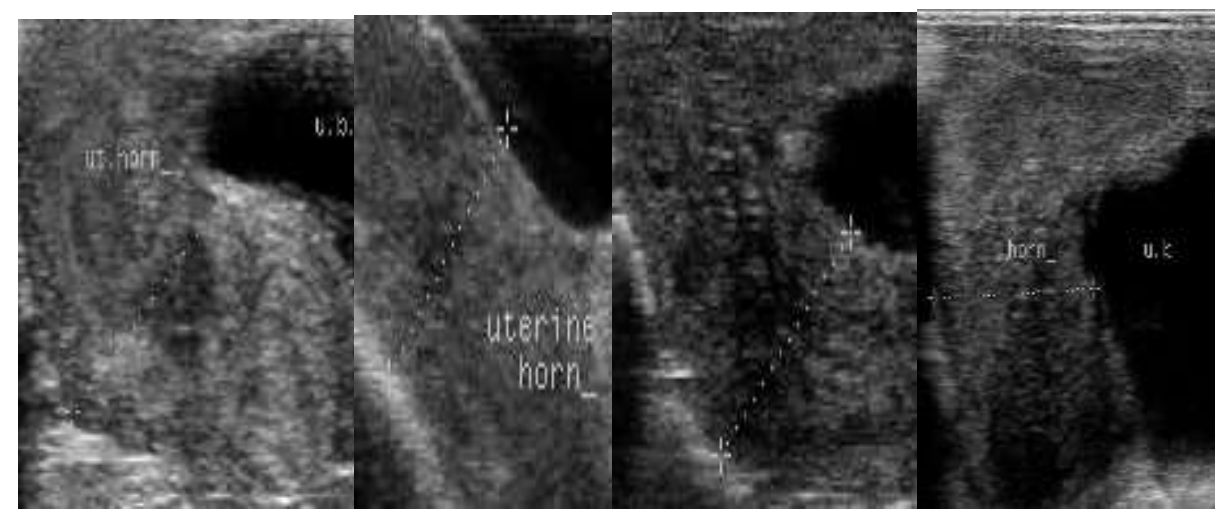

Fig 1. Site of taking the measurements of the involuted uterine gravid horn in farafra ewes 


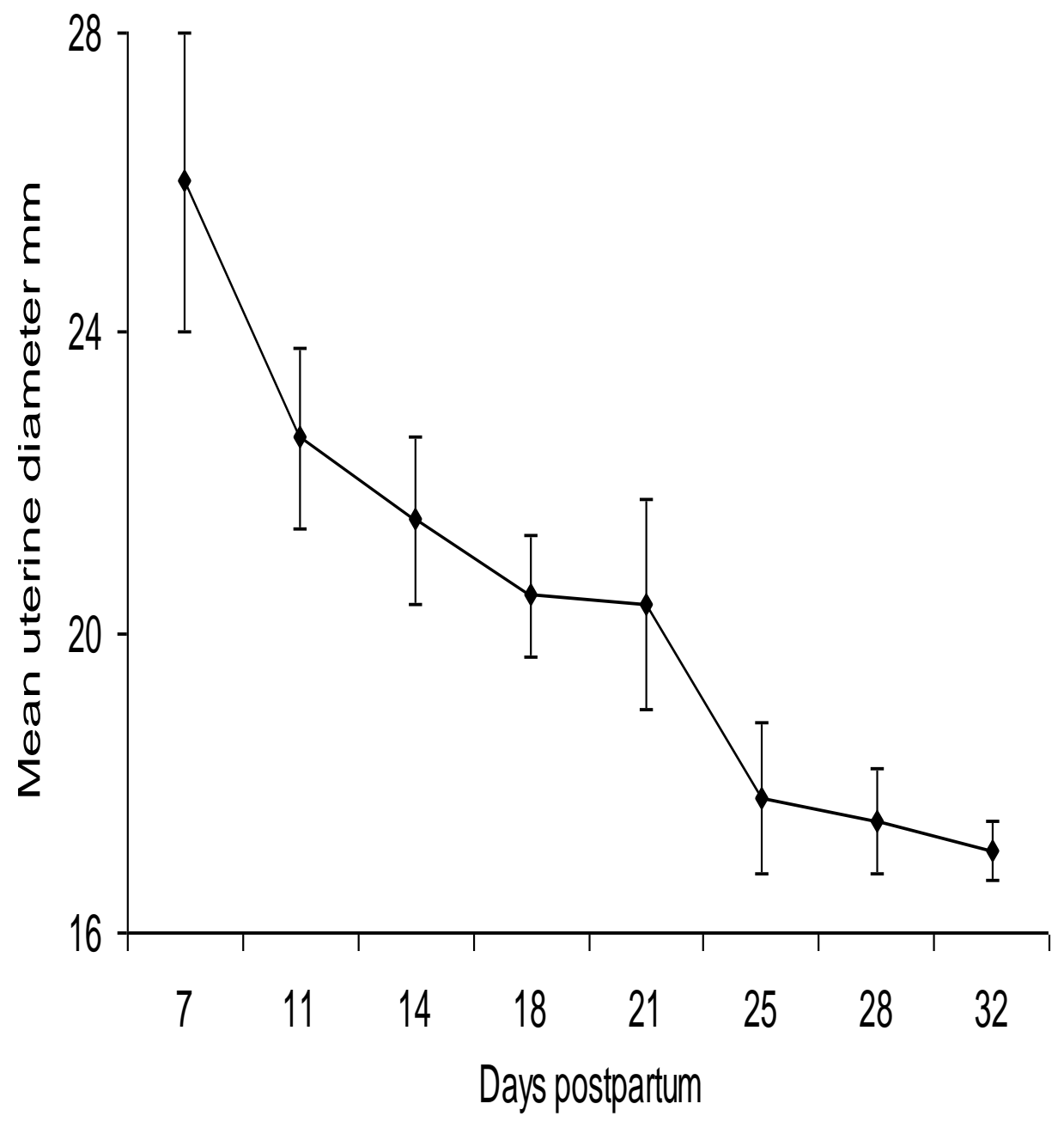

Fig. 2: Uterine diameter changes during the postpartum period in Farafra ewes that lambing in October. 

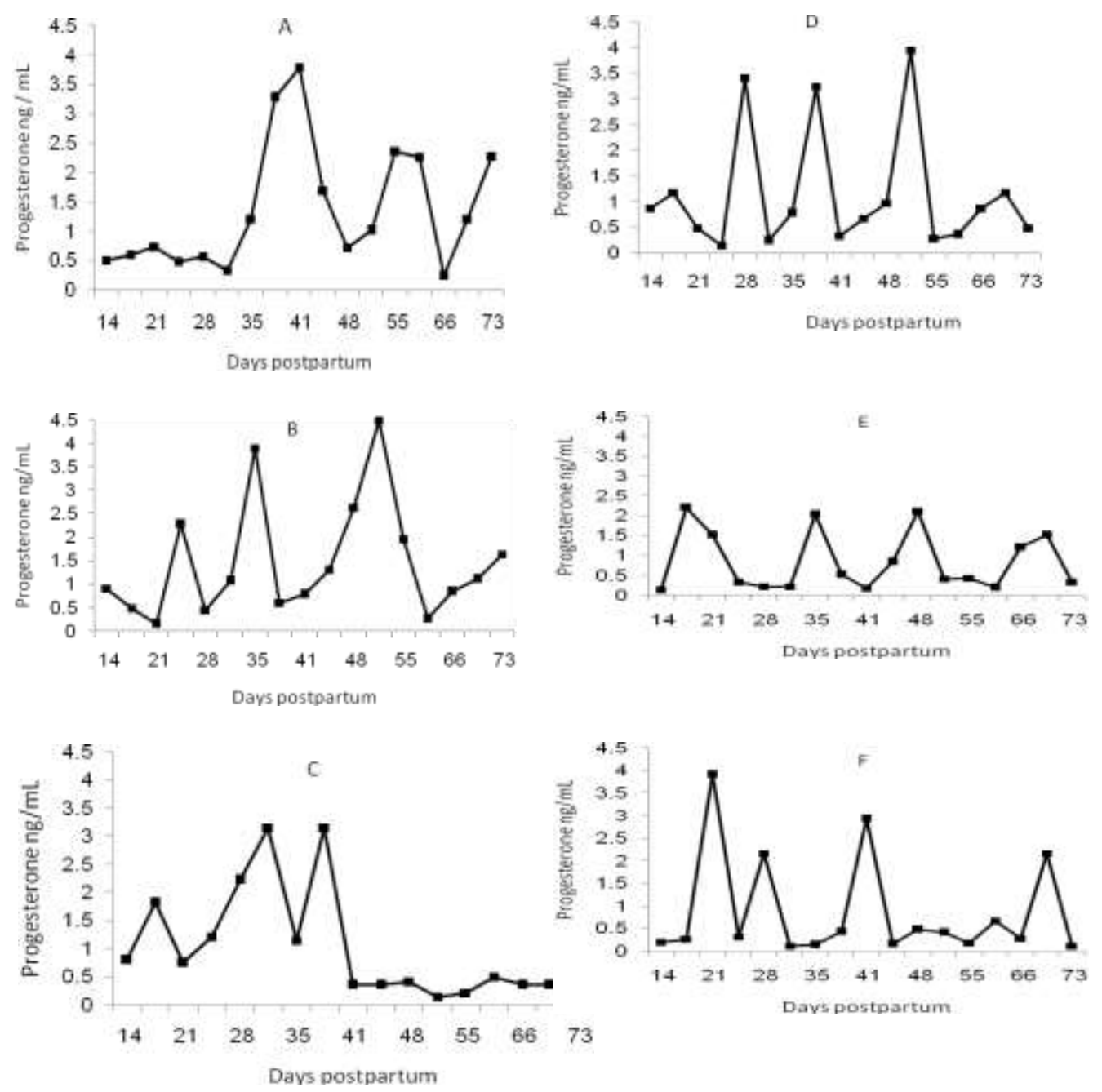

Fig. 3: Serum postpartum progesterone profiles in Farafra ewes that lambing in October ( $n=6)$, A: ewe showed two complete cycles (16d, 18d); B: ewe showed two short cycles (7d, 10d) and one complete cycle (21 d); C: ewe showed one short cycle (7d), one complete cycle (20 d) followed by cessation of luteal activity.; D-F: ewes showed more than one short cycle (from $7 \mathrm{~d}$ to $10 \mathrm{~d}$ ). 


\section{DISCUSSION}

Results of the present study are summarized in Fig. 1, 2 and 3. The mean interval for complete uterine involution for Farafra ewes that lambed in October was $28.72 \pm 1.0 \mathrm{~d}$, which is slightly shorter than that recorded by Hayder and Ali (2008) for Farafra ewes lambed in February $(29.42 \pm 1.2)$ and June $(33.85 \pm 1.1 \mathrm{~d})$. The time to completion of uterine involution has been reported to occur by 3 weeks postpartum in wool ewes in temperate climates (Kiracofe, 1980) and by 4 weeks postpartum in St. Croix White hair sheep ewes in the tropics (Godfrey et al., 1998). Throughout the examined period, no visible abnormalities in the uterus or pathological findings were found confirming that the reduction of the uterine size is physiological. Using the criterion of three examinations with nearly no change in the uterine measurements, as an indicator for complete uterine involution, was previously reported by Hayder and Ali (2008). Uterine involution was considered completed when there was no measurable decrease in cross-sectional area of the uterine horns in ewes (Godfrey et al., 1998).

The proportion of Farafra ewes that had corpora lutea within 35 $\mathrm{d},>35-42 \mathrm{~d}$, and > $42 \mathrm{~d}$ of lambing were $72.5 \%$ (29/40), $15 \%(6 / 40)$, and $12.5 \%(5 / 40)$ following October lambing, respectively, which is evidently shorter than those observed for Farafra ewes lambed in February $(12.1 \%, 24.2 \%$, and $63.7 \%)$ and June $(53.7 \%, 36.6 \%$, and 9.7\%), respectively (Hayder and Ali, 2008). Farafra ewes that lambed in October showed a progesterone concentration greater than $1 \mathrm{ng} \mathrm{mL}^{-1}$ on an average $22.0 \pm 2.5 \mathrm{~d}$ following lambing, which is obviously shorter than that noticed for Farafra ewes lambed in February $(39.0 \pm 1.2 \mathrm{~d})$ and June (69.3 $\pm 1.2 \mathrm{~d}$, Hayder and Ali, 2008).

It has been demonstrated in the same flock that following June lambing, 3/5 ewes showed a complete estrous cycle (17-18 days length), and $2 / 5$ ewes displayed a short cycle (7-9 days length) within the same examination period. In contrast, following February lambing non of the studied ewes had a complete estrous cycle (0/6), and only one ewe (1/6) showed a short cycle (11 days length) within the same period (Hayder and Ali, 2008). Similar findings were reported in Texel ewes (Mandiki et al., 1993). Corpora lutea have been observed in $67 \%$ and $75 \%$ of the PeliBuey ewes by d 20 and 30 postpartum, respectively (Gonzalez et al., 1987).

Among ewes that sampled for progesterone for $73 \mathrm{~d}$ following October lambing season, 3/6 showed at least one complete estrous cycle 
and 3/6 showed more than one short cycle during the observation period. These findings are supported by previous studies in hair sheep ewes (Godfrey et al., 1998). It was cited that, as in the normal estrous cycle, progesterone produced by the corpus luteum is probably necessary to stimulate the brain before estrogen will induce the first postpartum estrus (Robinson, 1954). In most post partum ewes, 1-3 short luteal phases were observed before the first behavioral post partum estrus (Kotwica et al., 1990). It was indicated that, observation of several short cycles in different sheep breeds meant that the reproductive tract appears acceptable for rebreeding several weeks before the ewes show behavioral estrus (Call et al., 1976; Wildeus et al., 1991). It was shown that progesterone $(\mathrm{P} 4)$ treatment during the restricted suckling period aids the early postpartum return and detection of oestrus (Diskin et al., 2001; Mandiki et al., 1993). In postpartum cows, it was suggested that the uterus may loss progesterone dominance at an earlier time during a short oestrous cycle. This would allow the synthesis of oxytocin receptors and initiate the positive feedback loop between oxytocin and $\mathrm{PGF}_{2} \alpha$ which leads to a premature release of $\mathrm{PGF}_{2} \alpha$ (Zollers et al., 1993).

In conclusion, it seems from the present data that the majority of Farafra ewes regain their ovarian activity (indicated with hormonal level and presence of corpora lutea) and nearly the non pregnant status of the uterus within 35 days after parturition. Moreover, 50\% of Farafra ewes expressed short cycles during the post partum period.

\section{REFERENCES}

Ali, A.; Derar, R. and Hussein, H. (2006): Seasonal variation of the ovarian follicular dynamics and luteal functions of sheep in the subtropics. Theriogenology, 66: 463-469.

Call, J.W.; Foote, W.C.; Eckre, C.D. and Hulet, C.V. (1976): Postpartum uterine and ovarian changes, and estrous behavior from lactation effects in normal and hormone treated ewes. Theriogenology, 6: 495-501.

Diskin, M.G.; Mackkey, D.R.; Stagg, K.; Roche, J.F. and Sreenan, J.M. (2001): Shortening the interval to the resumption of ovarian cycles in post-partum beef cows. Teagasc beef production series. Teagasc AFDA, Ballsbridge, Dublin, 25. 
Godfrey, R.W.; Gray, M.L. and Collins, J.R. (1998): The effect of ram exposure on uterine involution and luteal function during the postpartum period of hair sheep ewes in the tropics. J. Anim. Sci., 76: 3090-3094.

Gonzalez, A.; Murphy, B.D.; de Alba, M.J. and Mann, GJ. (1987): Endocrinology of the postpartum period in the PeliBuey ewe. J. Anim. Sci., 64: 1717-1724.

Goodman, R.L. (1994): Neuroendocrine control of the ovine estrous cycle. The physiology of reproduction. Eds: Knobil E., Neill J.D. Raven Press Ltd, New York, 659-709.

Hayder, M. and Ali, A. (2008): Factors affecting the postpartum uterine involution and luteal function of sheep in the subtropics. Small Rum. Res., 79: 174-178.

Kiracofe, G.H. (1980): Uterine involution: Its role in regulating postpartum intervals. J. Anim. Sci., 51(Suppl. 1): 1628.

Kotwica, G.; Kucharski, J.; Milewski, S.; Mercik, L.; Tański, Z.; ZezulaSzpyra, A. and Doboszyńska, T. (1990): Studies of the course of the postpartum period in sheep of the Polish Merino breed. III. Progesterone level in the peripheral blood 1-40 days after labor. Pol Arch Weter., 30(1-2):127-36 (abstract).

Mandiki, S.N.M.; Bistera, J.L. and Paquaya, R. (1993): Effects of hormonal manipulation on the resumption of postpartum reproductive activity in Texel ewes. Theriogenology, 40: 607-620

Robinson, T.J. (1954): The necessity for progesterone with estrogen for the induction of recurrent estrus in the ovariectomized ewe. Endocrinology, 55: 403.

SPSS. (2001): Copyright ${ }^{\circledR}$ SPSS for Windows, Version 11.0, SPSS Inc.

Stabenfeldt, G.H.; Ewing, L.L. and McDonald, L.E. (1969): Peripheral plasma progesterone levels during the bovine oestrous cycle. J. Reprod. Fertil., 19: 433.

Swanson, L.V.; Hafs, H.D. and Morrow, D.A. (1972): Ovarian characteristics and serum $\mathrm{LH}$, prolactin, progesterone and glucocorticoid from first estrus to breeding size in Holstein heifers. J. Anim. Sci., 34: 284. 
Wildeus, S.; Foote, W.C. and Evans RC. (1991): Characteristics of the post partum interval in the St. Croix hair sheep ewe. J. Anim. Sci., 69(Suppl. 1): 448 (Abstr.).

Wright, P.J.; Geytenbeek, P.E.; Clarke, I.J. and Findlay, J.K. (1983): LH release and luteal function in post-partum acyclic ewes after the pulsatile administration of LH-RH. J Reprod Fertil., 67: 257-262.

Zollers, W.G.; Garverick, H.A.; Smith, M.F.; Moffatt, R.J.; Salfen, B.E. and Youngquist, R.S. (1993): Concentrations of progesterone and oxytocin receptors in endometrium of postpartum cows expected to have a short or normal oestrous cycle. J. Reprod. Fertil., 97: 329-337. 